\title{
CZU:632.936:632.7 \\ https://doi.org/10.53040/gppb7.2021.84 \\ COMBATEREA INSECTELOR DĂUNĂTOARE CULTURILOR DE SERĂ PRIN ATRAGEREA ŞI EXTERMINAREA ACESTORA CU AJUTORUL CAPCANEI CU LUMINĂ
}

\author{
Gorban Victor, Todiraș Vladimir, Voineac Vasile, Savranschii Denis \\ Institutul de Genetică, Fiziologie și Protecție a Plantelor, Chișinău, Republica Moldova \\ e-mail: victor.gorban@igfpp.md
}

\begin{abstract}
The effectiveness of the integrated protection system is largely determined by the quality of pest development monitoring, which can be successfully performed by using devices with ultraviolet light sources with a certain wavelength. In order to carry out surveillance in order to signal the appearance of the main pests of the tomato crop, especially the mining moth, it is reasonable to develop new technologies and methods of protection of this crop, using in existing protection systems electro-optical devices light traps ultraviolet.
\end{abstract}

Key words: electro-optical, monitoring, light traps.

\section{Introducere}

Molia minieră de tomate - Tuta absoluta este un dăunător agricol, care infectează plantele din familia Solanaceae. Principala sursă de hrană a acestei insecte sunt tomatele. Acest dăunător este deosebit de periculos deoarece se obișnuiește destul de repede cu diferite tipuri de insecticide, ceea ce reduce semnificativ eficacitatea acestora și, deasemenea, datorită voracității sale excepționale și adaptabilității la condițiile de mediu nefavorabile.Lupta împotriva moliei miniere este și mai complicată datorită faptului, că acest dăunător poate ierna în oricare dintre ipostazele sale - de la ou la imago, iar larvele în stadiul de pupă atât în mijlocul minei, cât și în sol. Cel mai eficient mod de combatere a moliei miniere ar trebui să fie cuprinzător și sistemic, adică să includă toate măsurile de control existente împreunăcu prevenirea dăunătorilor. În prezent cele mai răspândite modalități de combatere a dăunătorilor sunt cele:- chimice; agrotehnice; - biologice.

\section{Materiale și metode}

În procesul studiului problemei în cauză s-au efectuat cercetări științifice, în rezultatul cărora , în cele din urmă s-a elaborat un dispozitiv inovativ (1), care în mod special este conceput pentru protejarea culturilor din seră de insecte dăunătoare şi vizează de diminuarea densităţii acestora, prin utilizarea surselor de radiaţii ultraviolete şi ecranelor adezive detaşabile de diferite culori.

Este cunoscută capcana de tip staţionar pentru monitorizarea şi capturarea insectelor, în care ca sursă de atracție sunt utilizate ecrane cu adeziv de diferite culori, iar pentru exterminarea lor este folosit colectorului cu lichid fixator (2).

Dezavantajul acestei capcane este utilizarea joasă a efectului de atracţie prin urmare eficacitate procesului de monitorizare şi combatere a insectelor dăunătoare este joasă.

Problema pe care o rezolvă invenţia propusă este diminuarea numărului insectelor dăunătoare la culturile de seră prin mărirea efectului de atracţie selectivă a diferitor specii prin utilizarea sursei de radiaţie optică şi a ecranelor adezive detaşabile de diferite culori şi colectorului cu lichid fixator cu proprietăți de reflectare a razelor ultraviolete.

Noutatea propunerii se datoreşte faptului, că pentru sporirea eficienţei de atragerea adulţilor moliei, ca sursă de radiaţie optică este folosită o lampă cu raze ultraviolete, cu lungimea de undă 310-365nm, cu un efect maxim de atragere a insectelor dăunătoare, amplasată deasupra colectorului de insecte. Pentru sporirea efectului de exterminare a dăunătorilor ecranele reflectoare sunt confecţionate din material de culori cu efect pronunţat de atracție a diferitor specii de insecte dăunătoare specifice culturilor de seră cu aplicarea unui adeziv, iar colectorul de insecte este îndeplinit în formă de vas cilindric detaşabil cu lichid fixator, care având proprietatea de a reflecta razele ultraviolete contribuie, în același timp, la amplificarea efectului de atracție a insectelor. Invenţia se explică prin Fig 1, care reprezintă schema ei principială de ansamblu. 
Esenţa invenţiei constă în aceea, că dispozitivul pentru atragerea şi exterminarea dăunătorilor include: corp1, sursă de radiație optică 2 cu lungime de undă 310-365 nm amplasată deasupra colectorului cilindric detașabil de insecte $3 \mathrm{cu}$ lichid conservant cu proprietăți de reflectare a razelor ultraviolete 4 , separator 5 executat din plasă, ecrane reflectoare detaşabile 6 de culoare atractivă cu adeziv, sursă de alimentație 7 și fotosensor 8 pentru includere automată a sursei de lumină.

Dispozitivul propus funcţionează după cum urmează: în încăperile serelor unde se cultivă plante agricole, în special tomate, se instalează dispozitivul şi se pregăteşte pentru exploatare, se cuplează vasul cilindric detaşabil cu lichid fixator, se instalează ecranele adezive detaşabile, se include butonul de start în regimul de aşteptare. Fotosensorul la orele de noapte dă comandă de activare a sursei de lumină. In perioada de maximă activitate a isectelor noctuide, având fototaxisul pozitiv ele sunt atrase de sursa de lumină spre dispozitiv unde sunt căpturate de elementele prevăzute - ecranele adezive detaşabile şi vasul cilindric detaşabil cu lichid fixator. În coliziune cu ecranele reflectoare adezive insectele se lipesc de suprafaţa lor lipicioasă. Lichidul fixator, având proprietăţi de reflectare a razelor ultraviolete de asemenea atrage o mare parte de insecte dăunătoare, care cad în mediul lichidului și pier, astfel se majorează eficacitatea măsurilor de combatere. Materialul obţinut poate fi studiat atât din punct de vedere sistematic cât şi numeric pentru obţinerea dinamicii de zbor a fiecărei specii de insecte dăunătoare prezente în seră.

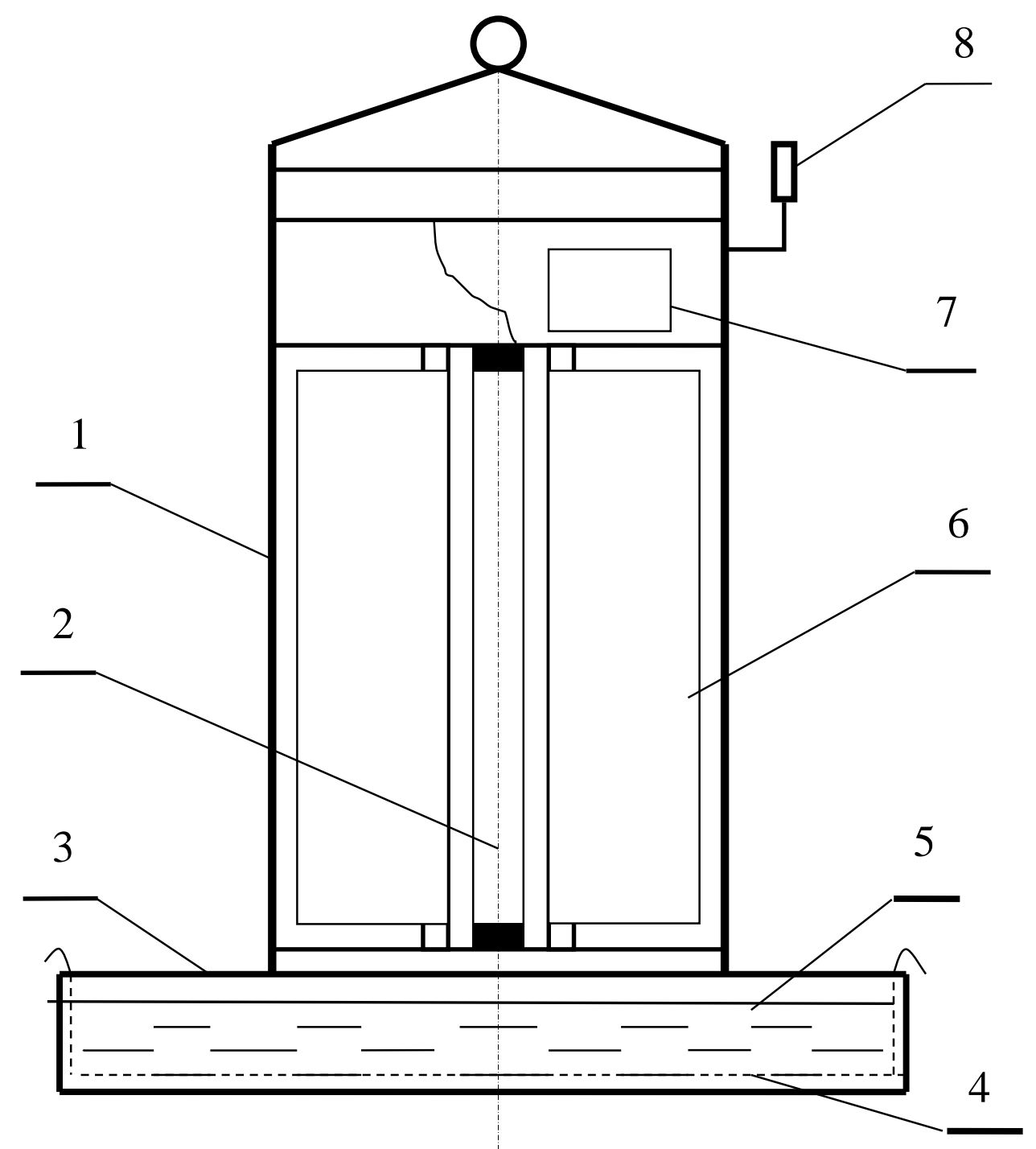

Fig 1. Schema principială a dispozitivului pentru atragerea și exterminarea insectelor dăunătoare culturilor de seră 
Rezultatul tehnic obținut se datoreşte faptului, că el asigură amplificarea efectului de atracție a insectelor dăunătoare prin utilizarea unei surse de lumină cu lungime de undă în intervalul 310-365nm, care contribuie la sporirea eficacității de exterminare ulterioară cu ajutorul ecranelor adezive detaşabile şi colectorului de insecte îndeplinit în formă de vas cilindric detaşabil cu lichid fixator. Controlul numărului de dăunători în sere, folosind dispozitivul propus, contribuie la reducerea semnificativă a numărului de dăunători prin exterminarea sistematică a acestora, limitând la minimum consumul de insecticide. Acest dispozitiv poate fi utilizat şi pentru cercetări entomologice, care permit nu numai efectuarea studiului mai complet al faunei de insecte, dar şi stabilirea raportului cantitativ dintre specii.

\section{Concluzii}

Pe baza acestei invenții se prevede elaborarea unei tehnologii de utilizare a dispozitivelor electrooptice, care va permite minimalizarea utilizării produselor chimice ca mijloace de combatere a principalilor dăunători ai culturilor de seră, în special ale tomatelor. Utilizarea capcanelor cu lumină la protecţia plantelor din seră vă permite să se obţină producţie ecologic pură, în acelaşi timp, îmbunătăţind calitatea legumelor la nivelul standardelor existente.

Modul de capturare a insectelor dăunătoare şi aplicarea, cu acest scop, a capcanelor cu lumina, la baza cărora este pus efectul de atracţie de către sursa de radiaţie ultravioletă a insectelor dăunătoare, este important și pentru identificarea speciilor de dăunători, în circumstanţele specifice ale suprafețelor protejate. Controlul numărului de dăunători în sere, folosind dispozitivul propus, va contribuie la reducerea semnificativă a numărului de dăunători prin exterminarea sistematică a acestora, limitând la minimum consumul de insecticide.

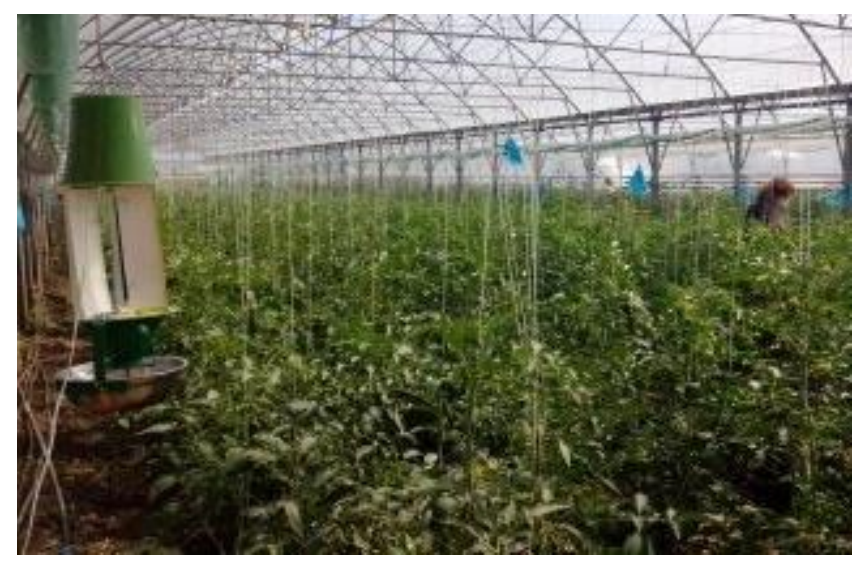

Fig 2. Vederea generală a dispozitivului pentru atragerea și exterminarea insectelor dăunătoare amplasat în seră la cultura de tomate

Cercetările au fost realizate în cadrul proiectului Programului de Stat 20.80009.5107.19: “Consolidarea capacităților de prognoză și combatere a organismelor dăunătoare și analiză a riscului fitosanitar în protecția integrată a plantelor”, finanțat de Agenția Națională pentru Cercetare și Dezvoltare.

\section{Bibliografie}

1. GORBAN, VICTOR, TODIRAŞ, VLADIMIR, VOINEAC, VASILE. Dispozitiv pentru atragerea şi exterminarea insectelor dăunătoare. Brevet de invenţie MD 937 2016.03.31.

2. КОЗАРЖЕВСКАЯ Э.Ф., КНЯЗЯТОВА В.И., КСЕНОФОНТОВА Н.А. Цветовая ловушка для насекомых. RU № 18762, 17.05. 2002. 